\title{
Pacific Media Freedom 2011: A status report
}

Pacific Journalism Monographs
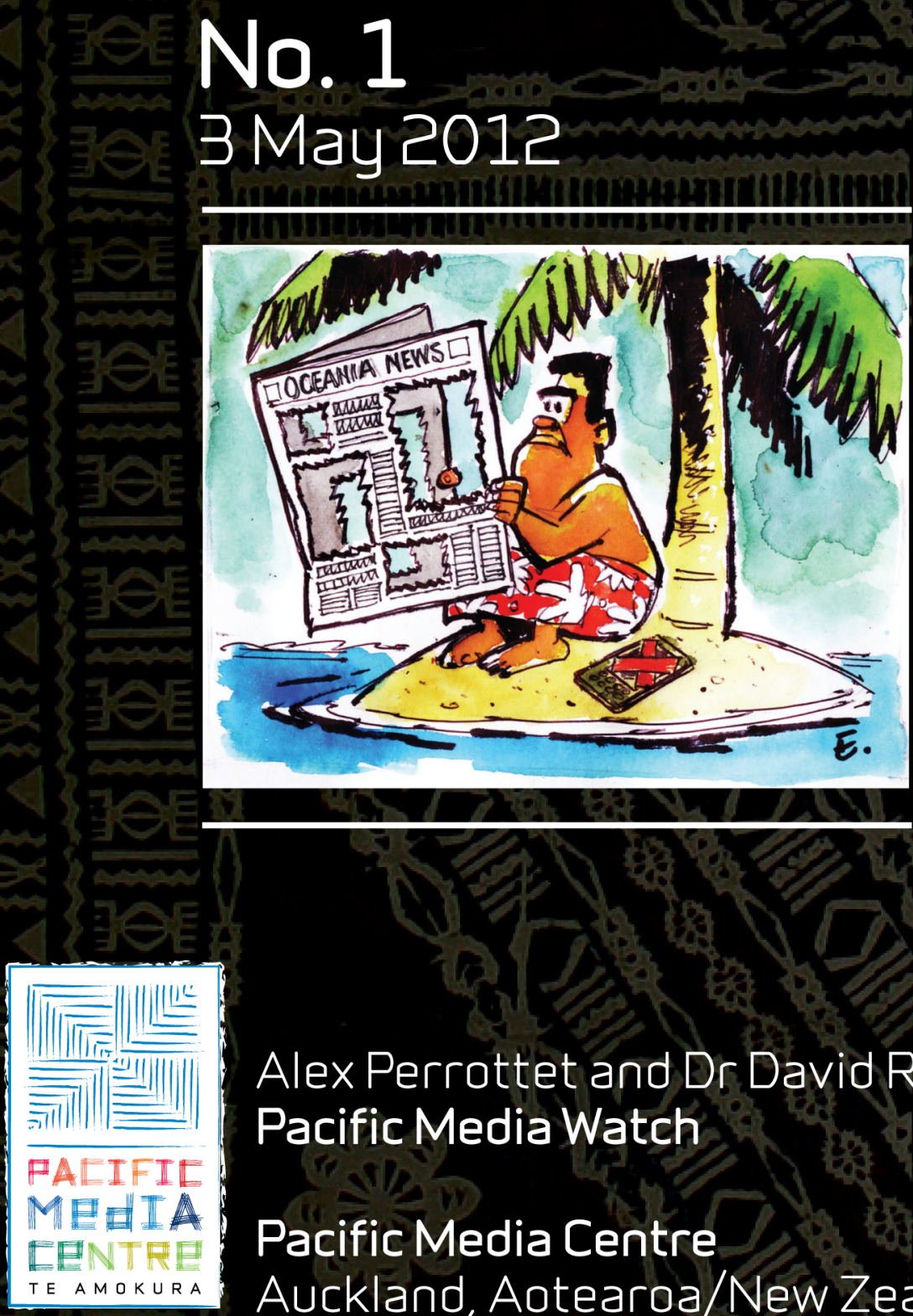

Alex Perrottet and Dr David Robie Pacific Media Watch

Pacific Media Centre

Auckland, Aotearoa/New Zealand

\section{A[D] COMMUNICATIONS}




\title{
Pacific Media Freedom 2011: A status report
}

Pacific Journalism Monographs

\author{
No. 1 \\ 3 May 2012
}

Alex Perrottet and Dr David Robie Pacific Media Watch 


\section{Pacific Journalism Monographs}

\section{No. 13 May 2012}

ISBN 978-1-927184-06-6

Republished from: Perrottet, A., and Robie, D. (2011). Pacific Media Freedom 2011: A status report, Pacific Journalism Review, 17(2), pp. 148-186.

www.pjreview.info/articles/special-report-pacific-media-freedom-2011-status-report-513

Published by the Pacific Media Centre

School of Communication Studies

Auckland University of Technology

Private Bag 92006

Auckland

Aotearoa/New Zealand

Website: www.pmc.aut.ac.nz

Monograph layout: Del Abcede

Cover design: Ryan Butler

Series general editor: Professor David Robie, director, Pacific Media Centre

(C) 2011/2 Pacific Media Centre. Monographs published occasionally. This is a double-blind peer refereed publication in accordance with the relevant university guidelines. 


\section{Pacific media freedom 2011: A status report}

\section{ABSIRACT}

Pacific media freedom has been under siege for more than a decade, particularly since an attempted coup in Fiji in May 2000, when a television station was attacked and ransacked, a foreign journalist was shot and wounded and a local journalist ended up being imprisoned for treason. Since then various Pacific countries, notably Fiji, Papua New Guinea, Tonga and Vanuatu have faced various periods of media repression. Since the military coup in December 2006, Fiji has faced arguably its worst sustained pressure on the media since the original two Rabuka coups in 1987. The Bainimarama regime in June 2010 imposed a Media Industry Development Decree that enforced draconian curbs on journalists and restrictive controls on foreign ownership of the press. This consolidated systematic state censorship of news organisations that had been imposed in April 2009 with the Public Emergency Regulations that have been rolled over on a monthly basis ever since. Promised relaxation of state censorship after the imposition of the Decree never eventuated. This research report covers the period 1 July 2010-31 August 2011 and examines the trends in the Pacific region. In addition to Pacific Islands Forum member nations, the report covers the French Pacific territories and the former Indonesian colony of East Timor and current provinces known as West Papua. ${ }^{1}$

Keywords: censorship, Fiji coups, freedom of expression, freedom of information, journalist safety, media ethics, media freedom, media law

\section{ALEX PERROTTET and DAVID ROBIE}

Pacific Media Watch

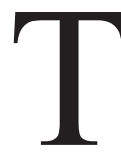

HE STATE of Pacific media freedom is fragile in the wake of serious setbacks, notably in Fiji, with sustained pressure from dation has continued with near impunity. Apart from Fiji, which has a systemic and targeted regime of censorship, most other countries are 


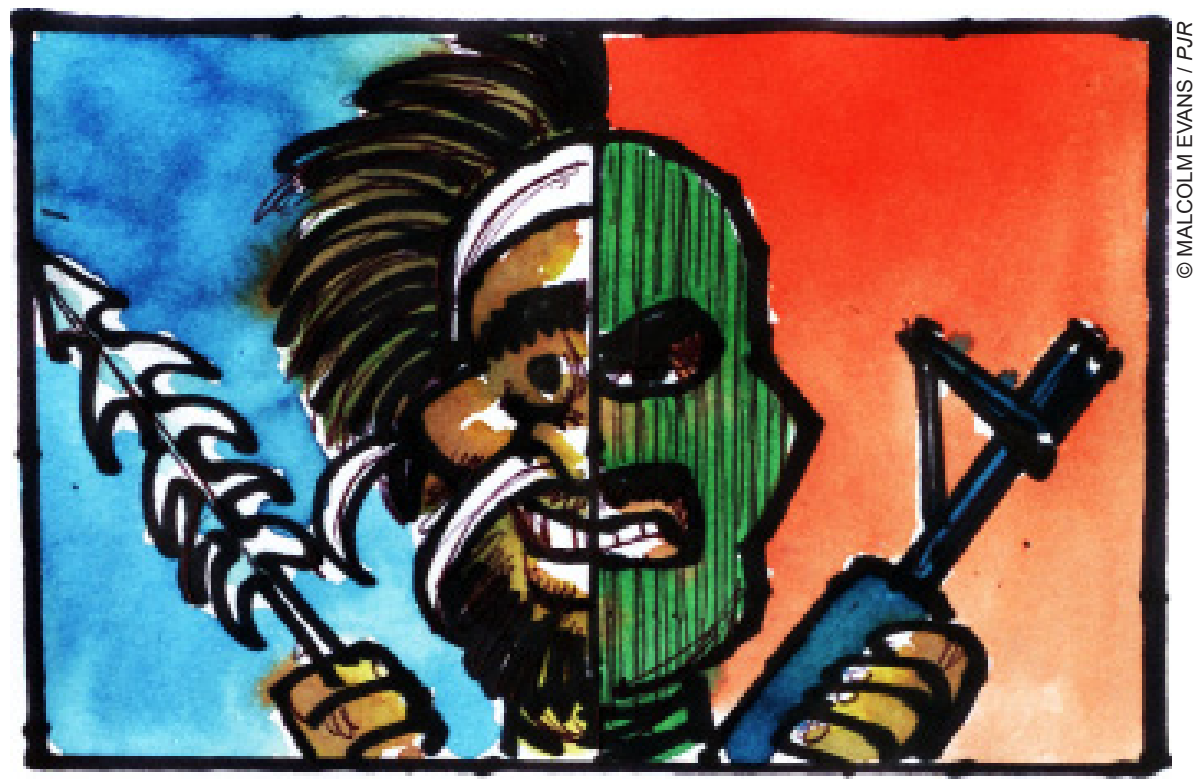

Figure 1: Indonesian-ruled West Papua: 'Most serious case of media freedom violations in the Pacific.'

attempting to free themselves from stifling restrictions on the press. Coupled with governments that are sluggish to introduce freedom of information legislation and ensure region-wide constitutional rights to free speech are protected, there are limited media councils and advocacy bodies with few resources to effectively lobby their governments. Those that do, run the risk of inviting backlashes by government figures who have a poor appreciation of the role of independent media in national development. For smaller countries, media is still largely under the thumb of governments and mainly an instrument for uncritically disseminating official information. Some, such as Tuvalu, have no commercial or privately-owned media.

Since the military coup in December 2006, Fiji has faced arguably its worst sustained pressure on the media since the original two Rabuka coups in 1987. The Bainimarama regime in June 2010 promulgated a Media Industry Development Decree on June 25. Four days later the new law enforced draconian curbs on journalists and restrictive controls on foreign ownership of the press. This consolidated systematic state censorship of news organisations that had been imposed in April 2009 with the Public Emergency Regulations 
that have been rolled over on a monthly basis ever since. Promised relaxation of state censorship after the imposition of the Decree never eventuated.

Fiji news media were given limited time to provide submissions with editorial managements being given merely two hours to read the 50-page draft law and make recommendations (Freedom House, 2011). A controversial issue about the Decree was a limit imposed on foreign ownership of not more than 10 percent, a clause vindictively aimed at the country's oldest and most influential newspaper, The Fiji Times (founded in 1869), because of its unrelenting opposition to the regime. This newspaper company was a subsidiary of News Ltd, the Australian branch of Rupert Murdoch's US-based News Corporation.

News Ltd sold the newspaper to a major Fiji trading house, the Motibhai Group and managing director Mahendra 'Mac' Motibhai Patel, a director on the Times for more than four decades, took control (Motibhai wins race, Café Pacific, 15 September 2010). Patel said: 'Fiji without the Fiji Times is unthinkable' (Rauto \& Baselala, 2010). He hired an Australian former Times publisher, Dallas Swinstead, to lead the newspaper in a more 'accommodating' direction to safeguard the survival of the business. Netani Rika, a campaigning editor who demanded a return to democracy, found his position untenable. His resignation was followed by deputy editor Sophie Foster a month later. Ironically, Patel himself was imprisoned after being found guilty of corruption in April 2011 in his role as chairman of Fiji Post (Fiji's top businessman jailed, Stuff Online, 14 April 2011). But the impartiality of the judiciary since the 2006 coup has been under question.

'During its history,' said a longstanding former editor, Vijendra Kumar, 'The Fiji Times has changed hands at least five times and has been none the worse for it. Each new owner infused it with new fresh ideas and better resources to ensure its continued growth and expansion' (Kumar, 2010).

Fiji journalists themselves are divided about the impact of the regime. Many opponents were beneficiaries under the ousted, discredited Laisenia Qarase government elected amid fears after the attempted May 2000 coup by maverick businessman George Speight and renegade special forces soldiers. Other journalists have taken the view that faced with the reality of working under a military regime, they would strive towards rebuilding the independence and integrity of Fiji's news media. According to Fiji Broadcasting Corporation news director Stanley Simpson: 
In the main, journalists today are not as confident (or as aggressive as some would describe it) as their counterparts were prior to 2006, and in the 1980s and 1990s. I am not saying that current journalists lack courage - in fact it is a courageous thing to be a journalist at this time. However, given the PER [Public Emergency Regulations], we are constantly checking ourselves and asking ourselves if the stories we write will breach the PER and what the consequences may be.

This is the longest period of censorship and public emergency regulations the country has experienced. More than two years and counting. How the Fiji media and journalists survive and adapt to the current environment is critical. Also important is how we adapt or react once the censorship and public emergency regulations is lifted.

Will the confidence return? What have we learnt? How aggressive will we be in getting a story? How freely will we report, and how responsible will we be? (Simpson, 2011)

While the case studies and statistics in this report may depict a media freedom situation that is relatively benign compared to many other countries, such as in the neighbouring states of Indonesia and the Philippines, which enjoy a nominally free press but pose serious dangers to journalists (Patindol, 2010; Soerjoatmodjo, 2010), there remain significant media freedom issues in most Pacific Island nations. Cultural issues involving the reconciliation of the ideals and values of a burgeoning media with the entrenched practices of compliance with traditional tribal or communal authority, and for the most part, small communities with many conflicts of interest. Other issues include problems of educating populations about dealing with the media, and a lack of access to media experienced by many communities.

Media bodies and associations have proliferated across the Pacific, many with conflicting aims and goals (Perrottet, 2011). This has caused dilemmas for a shrinking pool of aid donors. An ongoing feud between the Pacific Islands News Association (PINA) based in Fiji, and its breakaway former members and detractors is an example of such problems. The emergence of the Apia-based Pasifika Media Association (PasiMA) and the support for that organisation by influential Polynesian news media personalities such as Savea Sano Malifa and Kalafi Moala, have further fragmented the media landscape. Other groups include the Rarotonga-based Pacific Freedom Forum, aligned with the Sydney-based International Federation of Journalists Asia-Pacific 


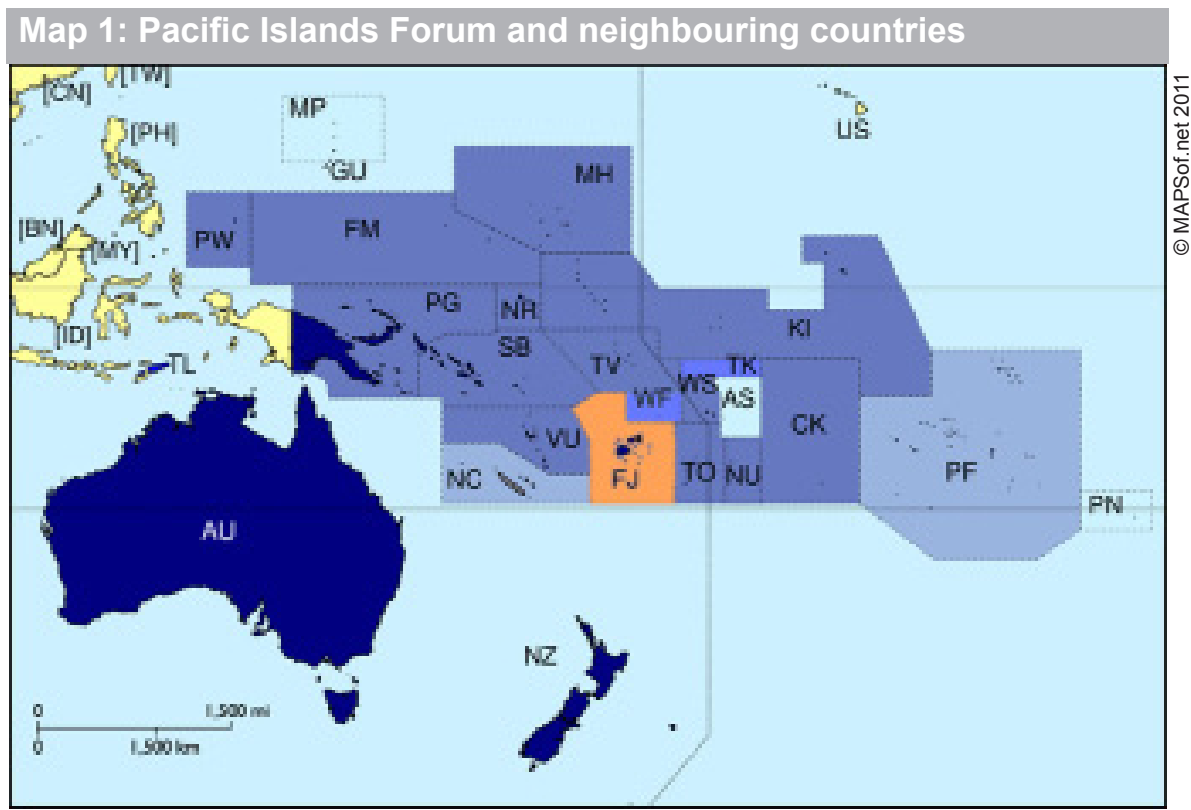

Key: Pacific Islands Forum (PIF) member countries: Australia (AU), Cook Islands (CK), Kiribati (KI), Marshall Islands (MH), Micronesia (FM), Nauru (NR), New Zealand (NZ), Niue (NU), Palau (PW), Papua New Guinea (PNG), Samoa (WS), Solomon Islands (SB), Tonga (TO), Tuvalu (TV), Vanuatu (VU). Suspended member: Fiji (FJ - suspended since 2 May 2009). Associate members / Observers: French Polynesia (PF), New Caledonia (NC), Timor-Leste (TL), Tokelau (TK), Wallis \& Futuna (WF). Indonesian-ruled provinces, Papua and West Papua (WP).

Office and the independent Auckland-based Pacific Media Centre and its Pacific Media Watch project.

Disagreement has previously emerged on the issue of PINA's remaining based in the military-controlled Fiji in spite of widespread opposition and reports of ongoing investigations by AusAID into allegations of funding irregularities in media development programmes (Pasima accuses PINA, PMC Online, 1 December 2010).

Clashes over media issues are not new, although they came to a head in Vanuatu in November 2010 when Vanuatu Daily Post publisher Marc Neil-Jones was strongly opposed by the Media Association Blong Vanuatu (MAV) when he applied for a radio licence (Perrottet, 2010). Evelyn Toa and PINA president Moses Stevens argued they were opposed to a 'Westerner's' influence on the Vanuatu airwaves, in spite of Neil-Jones having lived in Vanuatu for 17 years (Vanuatu media in radio licence row, $P M C$, 4 November 2010). They published vitriolic attacks against Neil-Jones in their publication, the Vanuatu Times, and Neil-Jones retaliated in his own daily publication (Ibid). 
Vanuatu provides an example of an intense media climate without any official censorship such as in Fiji. Neil-Jones's case in 2011 when he was assaulted by a group of men at the behest of a government minister was another event in a saga of violent reactions to his publication's reports (Publisher vows to press assault charges, $P M W, 5$ March 2011). Neil-Jones's direct, confrontational style has made him unpopular with several government figures in different administrations over some years and a minor fine for his political attacker prompted further dismay from international media freedom and human rights advocacy groups.

By far the most serious case of media freedom violations in the Pacific is in Indonesian-ruled West Papua (now split into two provinces in a 'divideand-rule' tactic by the authorities in Jakarta). Amid the backdrop of renewed unrest and mass rallies demanding merdeka, or freedom, with two bloody ambushes in Abepura on the outskirts of the capital Jayapura in early August, sustained repression has also hit the news media and journalists. In the past year, there have been two killings of journalists, five abductions, or attempted abductions, 18 assaults (including repeated cases against some journalists), censorship by both the civil and military authorities and two police arrests (but no charges) (see Table 1). Besides criminal libel, Papuan journalists are forced to contend with the crime of makar (subversion) as applied to the media. 'Also,' according to West Papua Media editor Nick Chesterfield, 'regular labelling of the Papuan press as being pro-separatist is another significant threat against journalists seen to be giving too much coverage to self-determination sentiment' (personal communication, 24 August 2011).

\section{Media freedom report statistics}

The digital divide between some Pacific countries and Western democracies, such as Australia and New Zealand, may seem to reflect sharply different media freedom priorities, yet the result is that arrests and infringement of individuals' privacy still occur. Australia and New Zealand are experiencing a major increase in the capacity of media technology and thus are engaging in their own development of laws regarding privacy and surveillance.

This report covers the period 1 July 2010-31 August 2011 and examines trends in the Pacific region. In addition to Pacific Islands Forum member nations, it covers the French Pacific territories and former Indonesian colony of East Timor and current provinces of Papua and West Papua (known 
collectively as West Papua). Examples and case studies reported in this report have been researched through Pacific Media Centre sources and regional and international press reports. Only examples verified by sources in media publications or other cross-checked sources have been included in Table 1.

Individual country statistics have been drawn from the United Nations Vital Statistics Report, mid-year estimate for 2009-2010 (http://unstats.un.org/ unsd/demographic/products/vitstats/serATab2.pdf); United Nations Development Program Report 2009, UNESCO Institute for Statistics, UNICEF and BBC News Country Profiles, PMC archives and the 2010 Indonesian census (Papua and West Papua). Internet penetration statistics have been drawn from Internet World Statistics (www.internetworldstats.com/pacific.htm).

\section{Australia}

Population: 22,342,398

Form of government: Constitutional monarchy

Language: English

Adult literacy rate: 99 percent

Internet penetration: 78.3 percent

Australia enjoys a high level of freedom of the press and a major step towards greater protection of journalists was taken in March 2011 when the Evidence Amendment (Journalists' Privilege) Bill 2010 was passed. This gives greater strength to shield protection for sources and reverses a previous presumption in federal evidence law favouring the disclosure of confidential sources. Since 2009, a wave of freedom of information reforms has swept through states, including NSW, Queensland and Tasmania, as well as the Commonwealth, all aimed at 'opening up' governments to the public with less bureaucratic red tape.

However, with an ever-increasing gap between technology and the law, there is always a grey area in which police and legislators, as well as those who push the limits, tread a fine line. In May 2011, Fairfax journalist Ben Grubb was arrested by police after writing an article about the vulnerabilities of Facebook's privacy controls (Journalist arrested, SMH Online, 18 May 2011). He was later released without charge while police confiscated his iPad. Grubb was at an IT conference and the speaker who was the subject of the article had hacked into a rival security consultant's wife's private Facebook page during a security seminar (Grubb, 2011). 


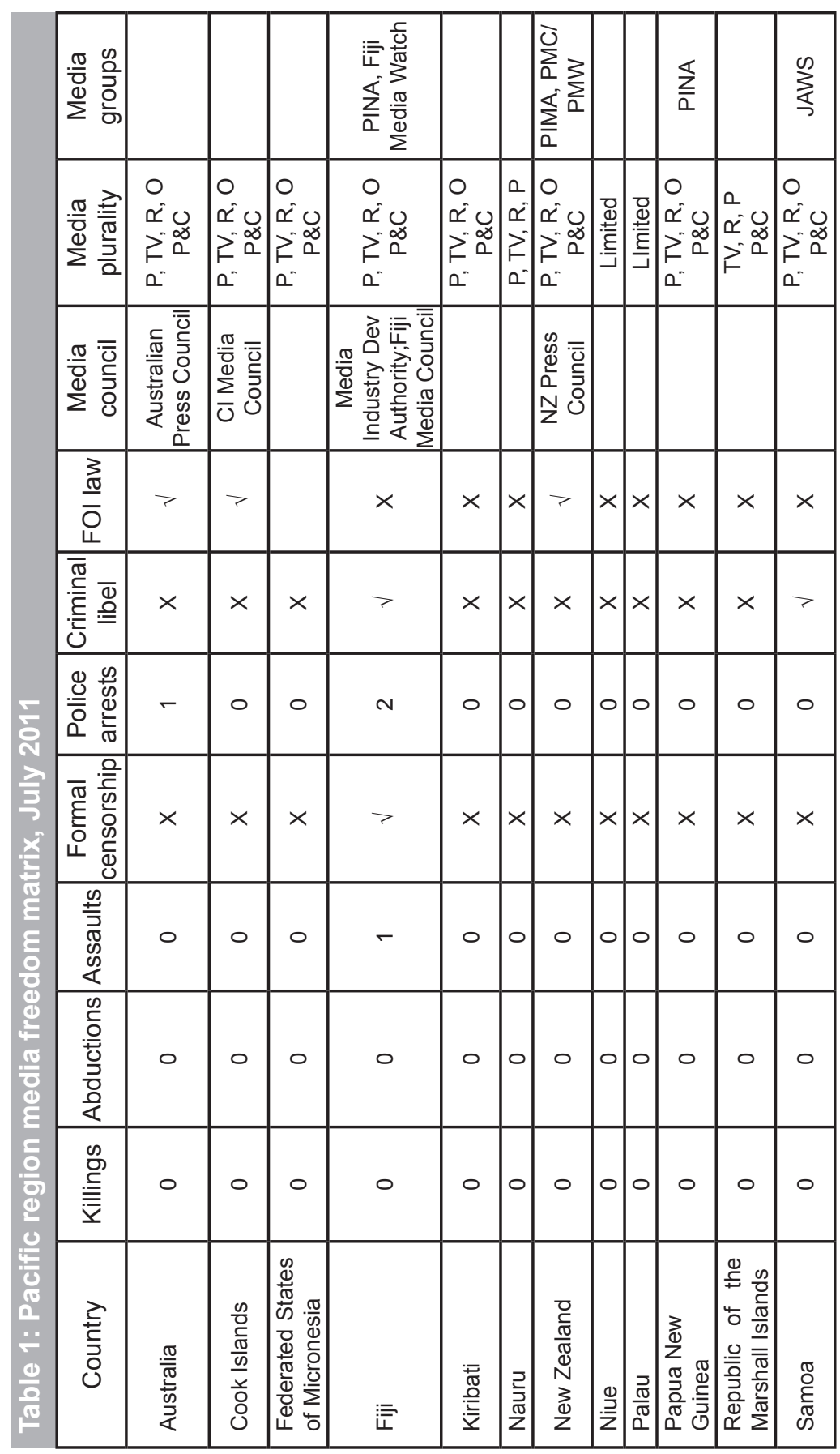

10 PACIFIC MEDIA FREEDOM 2011: A STATUS REPORT 


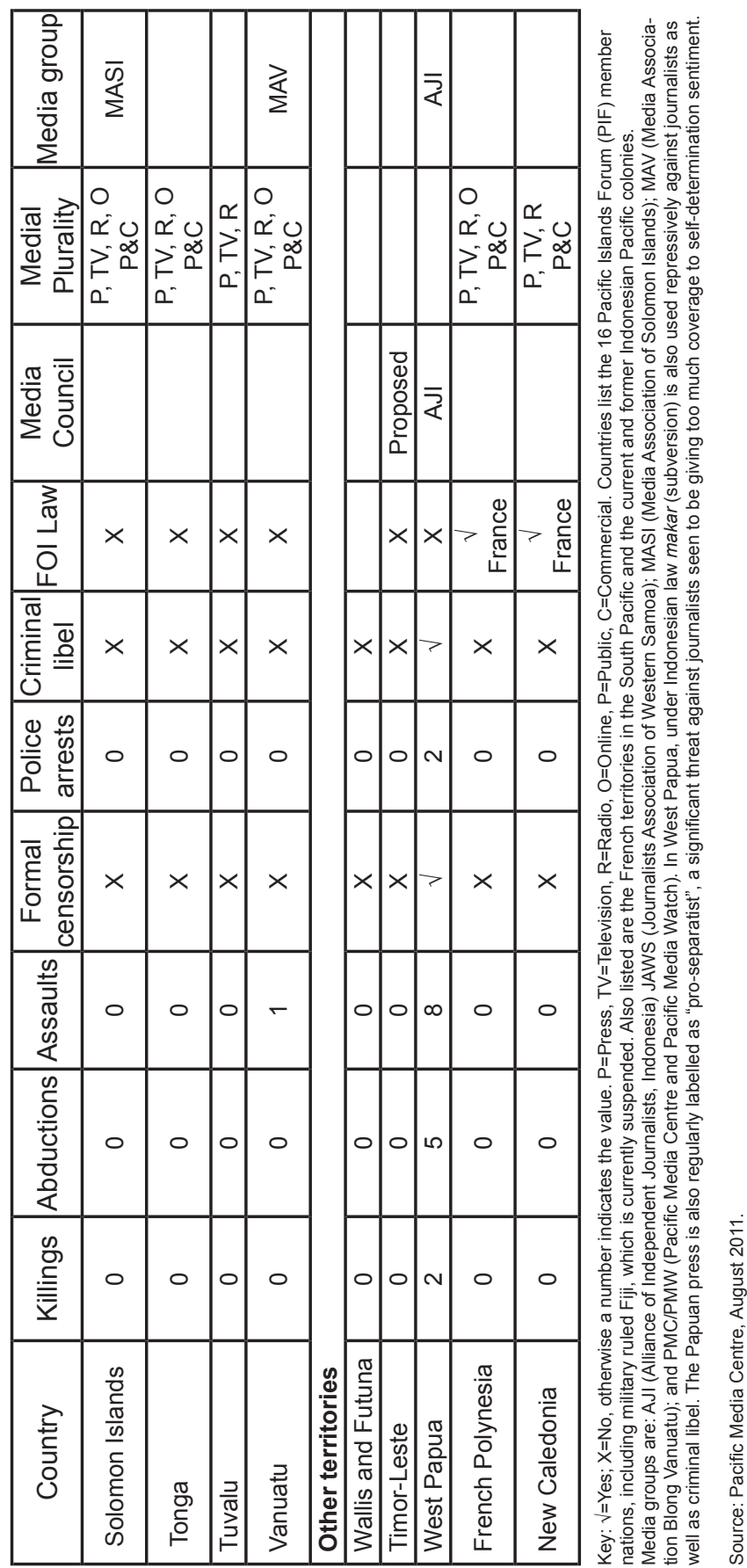

PACIFIC JOURNALISM MONOGRAPHS NO. 1201211 
Most developments in press freedom concern the expansion of social media and the ever-expanding ability to access information about individuals. In the wake of the News of the World phone-hacking scandal in Britain, the Australian government announced an inquiry into the extent of privacy laws, which could see greater protection for individuals against unwarranted press scrutiny (Bacon \& Price, $P M W, 9$ August 2011). However, there are serious concerns about the scope of the inquiry, as the government announced at the time of publication it would look at codes of practice and measures to strengthen the Australian Press Council. Reporters sans Frontières has questioned whether the inquiry, due to report back to the government in February 2012, is politically motivated (Is the government trying to get more control?, RSF, 16 September 2011).

In March 2011, the government welcomed the passing of the Telecommunications Interception and Intelligence Services Legislation Amendment Bill 2010. It gives wider powers for the Australian Security Intelligence Organisation (ASIO) to intercept information and is a major concern for the Media Entertainment and Arts Alliance (MEAA) because of wider provisions for sharing the results of its spying, according to its report on the state of media freedom in Australia in April 2010 (Progress under liberty, MEAA, 30 April 2010). Months later, the Intelligence Services Legislation Amendment Bill 2010 provided even greater powers for wiretapping offshore organisations such as Wikileaks. This bill became the subject of an inquiry by the Senate Legal and Constitutional Affairs Legislation Committee (New powers, Crikey, 18 May 2011). Furthermore, the Minister for Broadband, Stephen Conroy, proposed that the federal government implement a mandatory internet filter that would block child pornography among other undesirable material. The proposed debate has been delayed and has drawn criticism from freedom groups.

In November 2010 it was revealed that Northern Territory police had secretly accessed the telephone records of Darwin-based reporter Justin O'Brien and threatened legal action against him. They had been attempting to identify a confidential source (New threats to journalists' sources, IFEX, 15 November 2010). The Northern Territory Police Commissioner later said the police had not acted illegally as it was investigating a 'criminal offence'. Earlier in September, Victorian police admitted accessing phone records of a senior Herald Sun reporter, Geoff Wilkinson, and a 'handful' of other journalists to obtain information that would enable them to save face over an 
embarrassing whistleblower leak - which is a crime for a policeman (Simon Overland defends police checks, HS Online, 24 September 2010). Police Commissioner Simon Overland said politicians could also be monitored for similar reasons. Law enforcers are able to do this under exceptions in Part 13 of the Telecommunications Act and Chapter 4 of the Telecommunications (Interception and Access) Act.

\section{Cook Islands}

Population: 23,020

Form of government: Associated state (self-government in free association with New Zealand) Languages: English, Cook Islands Māori Adult literacy: 95 percent

Internet: 53.9 percent

The daily newspaper Cook Islands News is the largest independent publication and is also updated online with a selection of stories once a week. The weeklies Cook Islands Herald and Cook Islands Times also have online sites. Radio Cook Islands and Cook Island TV also operate in the country.

Cook Islands was the first Pacific Island country to introduce freedom of information legislation with the Official Information Act 2009 (Woods, 2010a, p. 15). However journalists complain that the Ombudsman struggles to oversee the law and, in practice, the system is 'handicapped' (p. 18). Cook Islands News editor-in-chief John Woods acknowledged the 'positive side' of the FOI law but criticised the political climate in which the newspaper's 'opinions on contentious issues draws scorn on an almost daily basis' (p. 18):

Our politicians revelled in it when they passed the law, even though it is still handicapped by lack of resources for education, and is still not really effective ... [In spite of the new law] the Cook Islands is still being denied the right to know at the highest level. The most powerful entity of government, cabinet, is still a stronghold of secrecy and nondisclosure. (Woods, 2010b)

Although there were reports by the Cook Islands News in May 2010 over threats and victimisation of one of the paper's journalists, Helen Greig (2010), no threats or intimidation were reported in the past year. In March, the Speaker of the Parliament threatened to take the Cook Islands News 
before the Parliamentary Privileges Committee over an article published about him in February. In November 2010, the Puna government was sworn in and the Office of the Head of State banned all but a select few media representatives from the normally open event (New Cook Islands PM sworn in, RNZI, 30 November 2010).

\section{Federated States of Micronesia}

Population: 107,839

Form of government: Mixed republic

Languages: English, Trukese, Pohnpeian, Yapese, Kosrean

Adult literacy: 92.4 percent (FSM Division of Statistics)

Internet: 15.9 percent

The Federated States of Micronesia consists of four separate states of Pohnpei, Chuuk, Yap, and Kosrae. While there is no daily newspaper, the bi-weekly private newspaper Kaselehlie Press is broadly circulated and is available online. There are several radio stations and each state has its own service. No instances of censorship and abuse of media freedom were recorded in the past year. However, in spite of media protocols being broadly based on the American system there is not yet any freedom of information legislation.

\section{Fiji}

Population: 882,066

Form of government: Military regime since December 2006

Languages: English, Fijian, Hindustani

Adult literacy: 94.4 percent

Internet: 16.6 percent

The main threat to media in Fiji is the ongoing censorship introduced by the military-backed government. The Media Industry Development Decree introduced in June 2010 had a number of direct effects, such as the sale of the News Ltd-owned Fiji Times to the Motibhai group, which led to the appointment of a new publisher, Australian Dallas Swinstead, the replacement of the editor Netani Rika and the deputy editor Sophie Foster. Both were outspoken critics of the regime and advocates of press freedom. They resigned within a month of each other when their positions became untenable. The newspaper began to take a more conciliatory editorial line 
to avoid having news reports and articles blocked from publication. After Swinstead resigned in January over contract and insurance issues, another Australian, Brian O'Flaherty, took over as publisher and general manager. The Public Emergency Regulations (PER) are still in place and they have been continually re-instated on a month-by-month basis, despite promises by the regime that they would be lifted in September 2010. PER directly impacts on the media and has resulted in the presence of military officers in newsrooms, the arrest and questioning of FijiLive journalist Richard Naidu and a brief suspension of the FijiLive news website in August 2010. Police also detained Fiji Times journalist Felix Chaudhry in February 2011 over an unflattering story exposing the plight of the sugar industry.

The rival Fiji Sun daily newspaper has benefitted from a monopoly on state advertising but still faces censors in the newsroom every night. The editor, Leone Cabenatabua, has explained that his newspaper is 'cooperating' (Frank, Uncensored reveals, ABC Pacific Beat, 5 August 2010). Weekend Sun editor Maika Bolatiki told New Zealand's 3News he supports the Decree, and it was necessary to write only positive articles to move the country forward. (Morrah, 2010)

The ongoing impact of the Decree is that the regime can imprison and fine journalists and there is a constant threat of this, directly eroding the independence of newsroom decisions. Critics say the long-established Fiji Media Council appears to have been largely sidelined under the Decree by the new state-established Media Industry Development Authority, where both government-appointed personnel work with representatives from the industry.

The Pacific Islands News Association (PINA) and Fiji Media Watch are making concerted efforts to run educational workshops, focusing on training the public to be critical readers of media information and on training families to protect children from being over-exposed to television and other media. Fiji Media Watch is campaigning for more women in the media. In July 2010 John Woods resigned as vice-president of PINA, adding to the ongoing debate among Pacific media staff over the role of the regional body, and contributing to the rise of a new group, PasiMA, founded in Samoa in August.

The news editor of the government-owned Fiji Broadcasting Corporation, Stanley Simpson is a well-respected and award-winning journalist who has been successful in balancing a fine line between appeasing the regime and criticising it. He has spoken at various seminars and explained his honest 
efforts to report as much as he can on 'development and progress' without being censored (Simpson, 2011). He notes many of the guidelines under the decree were similar to a national code of ethics deployed by the self-regulatory Fiji Media Council Ltd before the Decree was passed (Fiji Media Watch, n.d.). The privately-owned Communications Fiji Ltd has taken a similar approach and between them there are multiple radio frequencies broadcasting in Fijian, English and Hindustani. Recently there have been new frequencies opened up for the Fiji Broadcasting Corporation.

In August, Usaia Waqatairewa of the Fiji Democracy Movement said he was planning to send a Dutch pirate radio ship into Fiji waters to broadcast and circumvent censorship, but there has been no further reports about this.

The Citizens Constitutional Forum of Fiji, and its prominent leader Rev Akuila Yabaki have drafted and lobbied for a Freedom of Information Act. In May 2011 the Attorney-General, Aiyaz Sayed-Khaiyum, said the Act was a 'work in progress' (Work continues, FBC News, 24 May 2011).

\section{Kiribati}

Population: 92,533

Form of government: Republic

Languages: English, i-Kiribati

Adult literacy: 94 percent (International Labour Organisation)

Internet: 7.7 percent

Kiribati enjoys press freedom and has several media outlets, including the government-owned weekly Te Uekera. The privately-owned Kiribati Newstar, which celebrated ten years of publishing in 2010, and Mauri are the other independent weekly papers. Two radio stations, Radio Kiribati and FM96 operate along with Kiribati Television. Kiribati Community Online is published from the United States while the Kiribati Independent is published in New Zealand. There is no freedom of information legislation.

The Broadcasting and Publications Authority Ordinance 1979 still allows government control over the independent media and gives politicians wide powers over broadcasters. Independent newspapers have to register with the government, which has the power to withhold licences and has done so in the past. So far there is no media council in the country and only a small number of journalists. No instances of direct censorship or repression through violence or threat of violence were reported in the past year.

16 PACIFIC MEDIA FREEDOM 2011: A STATUS REPORT 
In March 2011, a Taiwanese grant enabled Radio Kiribati to extend its reach to the entire country.

\section{Nauru}

Population: 10,065

Form of government: Republic

Languages: Nauruan, English

Adult literacy: 99 percent

Internet: 3.2 percent

This Pacific country has limited news media. The only media is governmentowned and there is no daily news service. There is Nauru Television and Radio Nauru, but they mostly broadcast the ABC from Australia as well as the BBC. The Nauru Bulletin publishes weekly and the Central Star News every fortnight.

No direct censorship was reported in the past year. The country has not developed freedom of information legislation, nor does it have a media council.

\section{New Zealand (Aotearoa)}

Population: 4,367,800

Form of government: Constitutional monarchy

Languages: English, Māori, Sign

Adult literacy: 99 percent

Internet: 83.9 percent

New Zealand enjoys a free media climate and has boasted having the highest number of radio stations per capita in the world (Shanahan, 2011). The New Zealand Herald is the highest-circulation newspaper.

New Zealand journalists enjoy shield laws that Australia is now starting to imitate. However, submissions for the Search and Surveillance Bill were closed in September 2010. The Bill proposes wide-ranging powers for various authorities to search records and belongings, to spy, bug conversations and hack into private computers. It proposes to give police powers to 70 other state agencies. At the time of publication, the government had obtained the necessary support for the Bill to be passed, subject to a select committee hearing (ACT gives govt the necessary numbers to pass surveillance bill, RNZ, 20 September 2011) 
The Press Council and Broadcasting Standards Authority (BSA) are respectively self-regulatory and regulatory authorities that govern the press and broadcasting. The BSA frequently rules against and fines media organisations for breaching standards. In April 2011 it upheld a complaint against Television New Zealand for allowing the word ' $\mathrm{f} * * *$ ' spoken to go unedited in an early evening Sunday documentary about the Aramoana massacre in 1990 when David Gray murdered 13 people. The BSA ruled TVNZ had breached good taste and decency and children's interest standards in allowing the swear word to be aired before $8.30 \mathrm{pm}$. TVNZ appealed (TVNZ to fight Aramoana BSA decision, Stuff, 19 April 2011).

In May 2011, the BSA ruled against the Samoan government over a complaint against TV3's Campbell Live programme and current affairs reporter John Campbell over his reports challenging the issue of how \$59.4 million of tsunami relief funds had been spent (Hill, 2011). The Samoan government appealed to the High Court. The same month the Press Council upheld a complaint by NZ Foreign Minister Murray McCully against Michael Field and Marc Hinton and the Sunday Star-Times over a 'grossly inflated' story about Fiji dictator Voreqe Bainimarama and the World Rugby Cup on accuracy, fairness and balanced grounds (McCully complaint against Field story, $P M W, 11$ May 2011).

The current National government is frequently criticised over its attitude to public broadcasting. The government announced in April that it would cut funding to TVNZ7 and the following month it announced that it would also slash funding to Radio New Zealand's Waatea News (Māori content) and Concert FM (New Zealand planners, Pacific Scoop, 22 June 2011; Waatea News, Nga Reo Tangata, 15 July 2011). In response, a meeting of media people petitioned the government and agreed to set up a public broadcasting foundation.

In April, the New Zealand Press Association announced it would be closing in September after 130 years operating as the country's national news agency. NZPA employs about 40 journalists and produces more than 1000 news items a day. The move was triggered by the major shareholder Fairfax New Zealand, which had given notice that it planned to withdraw from the news cooperative (NZPA closing, NZ Herald, 6 April 2011). Former Dominion editor Karl du Fresne warned that an already meagre regional news coverage, including the South Pacific, would get worse: 'Even more worrying is that 
the existing "black holes" in news coverage will become wider and blacker still' (Du Fresne, 2011).

While media plurality is better than in many countries, the 18 -yearold New Korea Herald newspaper in New Zealand was forced to close in December after being ordered by the High Court to pay $\$ 250,000$ in damages for defaming a prominent Korean businessman (Tan, 2010).

However the Fiji regime exploited media 'unprofessionalism' in November 2010 when two New Zealand media outlets erroneously reported that the Fiji Prime Minister had 'died'. Bainimarama retorted: 'I know I am still alive' and the Fiji government threatened to file a lawsuit (Field, 2010).

There are also common complaints from within the media industry of a lack of funding for investigative journalism, a lack of industry support and recognition of investigative journalists and their work. In May 2011, awardwinning investigative journalist Jon Stephenson was forced to defend himself against a bitter attack on his credibility by Prime Minister John Key, officials and some fellow journalists over his investigative work with an article 'Eyes wide shut' in the May edition of Metro magazine (Stephenson, 2011). This article exposed the New Zealand military in Afghanistan in a controversial arrangement for handing over prisoners to US forces and their abuse (Playing the man, Public Address, 10 May 2011). Complaints against the magazine and a subsequent 60 Minutes television report were filed with the Press Council and Broadcasting Standards Authority respectively. In his September editorial, Metro editor Simon Wilson lambasted the NZ Defence Force, saying it:

began the process of a Press Council complaint against Metro, by writing to us to allege we had misrepresented the facts. They also initiated [BSA] complaints against TV3 and TVNZ over their coverage of the story. We rebutted each element of the NZDF's complaint, and the two broadcasters responded in similar terms. In the end, the Defence Force did not proceed with any of it. They have backed down. (Wilson, 2011)

As well as the Press Council complaint against Metro, three BSA complaints had been filed over Stephenson's reports-against TV3's 60 Minutes, TVNZ's Marae Investigates and Media7 (on the digital channel TVNZ7). All four complaints were dropped by the military. 


\section{Niue}

Population: 1,496

Form of government: Associated state (Self-government in free association with New Zealand)

Languages: Niuean, English

Adult literacy: 95 percent

Internet: 88.9 percent

A limited news media operates in 'The Rock', as this country is sometimes dubbed, with government-owned Niue Broadcasting Corporation running television and radio. A weekly news service is operated by the Niue Star. However, it has a high internet penetration and the population access international news through the internet. No cases of censorship or threats against journalists were reported in the past year.

\section{Palau (Belau)}

Population: 20,956

Form of government: Republic

Languages: Palauan, English

Adult literacy: 92 percent

Internet: 27.8 percent

Palau has a weekly newspaper, The Palau Tribune. The Palau Gazette is a monthly paper published by the government. There is also a fortnightly English-language Tia Belau. There is one state-owned radio and television broadcaster, but citizens have cable and satellite television, giving them access to international media. Island Times is a weekly paper that also has a website:www.islandtimes.us

The privately owned Oceania TV Network (oceaniatv.net) that broadcasts $24 / 7$ and produces a weekend locally produced news programme that includes news of Palau, Marshall Islands and the region. The OTV channel is also broadcast by both TV stations in the Marshall Islands and plans to expand to states in the Federated States of Micronesia.

No cases of censorship or threats against journalists were reported in the past year. Freedom of the press is guaranteed by the constitution, drawing on Fourth Estate principles from the US Constitution. But in November 2010, the Palau Horizon newspaper closed after publishing for 12 years, fuelling 
concerns over lack of media plurality. Publisher Abed E. Younis cited a 'negative business atmosphere' and a slow economy for the newspaper closure (Palau newspaper closedown, PFF, 5 March 2011).

\section{Papua New Guinea}

Population: 5,190,786

Form of government: Constitutional monarchy

Languages: English, Tok Pisin, Hiri Motu

Adult Literacy Rate: 57.8 percent

Internet: 2 percent

Papua New Guinea's traditional news media outlets this year faced their biggest challenge since independence in 1975 with constant political turmoil, culminating on August 2 with the overthrow of the National Alliance government and its ailing leader Sir Michael Somare. With a constant stream of nationwide allegations and counterclaims of endemic corruption, crumbling essential services such as health, transport and law and order, PNG's print and electronic media battled daily to report these events.

Before the August 2 parliamentary coup which saw a stampede of government MPs join the Opposition to overthrowing the incumbent, Acting Prime Minister Sam Abal, had publicly challenged the impartiality of the daily Post-Courier which is majority owned by Rupert Murdoch's News Corp (PNG acting PM accuses Murdoch daily, Pacific Scoop, 23 July 2011).

His action was widely rejected by local management and several former staff who insisted the newspaper operated independently of its owner on editorial policy. The Post-Courier's daily opposition, The National, owned by Malaysian logging giant Rimbunan Hijau, continued to outsell the older Post-Courier with faster national delivery based on a remote printing site in Lae. PNG's crumbling road network and air service disruptions hampered both newspapers' distribution networks in 2011.

The August 2 political coup changed PNG's media scene dramatically as overnight thousands of Papua New Guineans signed up to social media internet sites to read the latest reports and even look at smartphone photos of the new Prime Minister Peter O'Neil taken just minutes earlier inside the Parliament chamber. By mid-August, PNG had 50,000 Facebook users and one rising political MP now minister, Sam Basil, had more than 4000 followers on his page. 
In the week of leadership drama and endless court challenges, Facebook sign-ups in Papua New Guinea jumped by 17 percent to 48,000. Several Facebook pages set up by working journalists flashed constantly with news and comment on issues like the honesty of politicians and the stability of the country. In a single day some pages carried more words than a year's worth of letters to the editor in all national print media.

While Papua New Guinea ranks highly in international media freedom indexes, issues such as a review of codes of ethics and practice are likely to be on the agenda in Port Moresby later this year as PNG is due to host the annual Pacific Islands News Association (PINA) conference. Media watchdogs will keep a close eye on developments should the conference proceed. Disagreement has masked aired on the issue of basing PINA in the military-controlled Fiji and reports of ongoing investigations by AusAID of allegations of funding irregularities in media development programmes.

The Censorship Act prohibits the importation of obscene material and all radio programmes must comply with the Act's required standards. The Printers and Newspapers Act dictates that names of both the printer and publisher appear in the publication. The National Broadcasting Corporation (NBC) runs radio and there is a strong supporting presence of Australia's $\mathrm{ABC}$ as well as the BBC.

In December 2010, the government pressured the NBC into suspending executive news director Dorah Masseung, sparking an outcry from both RSF and PFF. The Post-Courier alleged Masseung was stood down by NBC managing director Memafu Kapera, who introduced further restrictions in the newsroom due to government complaints of 'biased' and 'negative' news coverage (Public media must be free, RSF, 15 December 2010).

Papua New Guinea media will face an even greater reporting challenge in 2012 with national elections due. Elections in previous years have been frequently marred by corruption claims, voting fraud and threats to journalists.

\section{Republic of the Marshall Islands}

Population: 54,305

Form of government: Republic

Languages: Marshallese, English

Adult literacy: 94 percent

Internet: 7.2 percent 
The Marshall Islands enjoys press freedom and it is protected by Article 2 of its Constitution. The limited media includes the privately owned weekly Marshall Islands Journal which also has a website and produces both print and digital editions. In Majuro, there are two cable TV companies, one run by the private company Marshalls Broadcasting Company; the other a digital broadcast station run by the National Telecommunications Authority (NTA). In Kwajalein, the US Army operates the Armed Forces Television Network,which is picked up by Ebeye Island residents. The Marshall Islands government operates a nationally broadcast AM radio station. There are two religious FSM stations on Majuro, and one commercial FM station that includes a lively news talk show format hosted by a former long-time Cabinet adviser. The President's Office maintains a regularly updated website. There is no freedom of information legislation or media council.

The national women's organisation, Women United Together Marshall Islands, recently launched an FM station that broadcasts from $8 \mathrm{am}-5 \mathrm{pm}$, providing music and a variety of talk shows focusing on its community advocacy programmes. A new newspaper, The Island Voice, started publication in Majuro in August 2011 on a weekly basis. Like the Journal, it is also independently owned.

No cases of censorship or threats against journalists were reported in the past year.

\section{Samoa}

Population: 184,032

Form of government: Republic

Languages: Samoan, English

Adult literacy: 98 percent

Internet: 4.7 percent

Despite a history of harsh restrictions and legal cases against publishers in Samoa, the past year has been relatively free of incident. The daily Samoa Observer, was joined online in February 2011 when the government-run Savali was launched. (www.savalinews.com) However, in May there were reports that Samoa was in dire need of trained journalists (Samoa lacks trained journalists, Samoa Observer, 10 May 2011). Other weekly and monthly newspapers and magazines serve the country, some published in 
New Zealand, and there is both commercial and government-owned radio and television.

While no cases of censorship or threats against journalists were reported in the past year, there are major concerns. Some draconian laws in Samoa constantly threaten journalists and their profession. The Printers and Publishers Act 1992 demands that journalists reveal confidential sources if a court order rules in favour of such a request by a member of the public. The same Act allows for government members to access public funds to finance legal actions against newspapers and other media outlets. The Samoa Observer editor-in-chief, Savea Sano Malifa, has been a vocal critic of the government and these laws. The government has eased its attacks on local media, and instead turned pressure on international media, lodging two different complaints against media in New Zealand in recent years. The most recent was a complaint filed with New Zealand's Broadcasting Standards Authority against TV3's Campbell Live report about the alleged misuse of tsunami aid funds. The complaint was turned down in May 2011 but the Samoan government has since appealed the decision.

The Observer and other media are generally 'respectful' to political leaders and over the past year media have been able to criticise the Prime Minister and the government without any reported reprisals. Also, the newspaper has apologised for 'erroneous reporting' and for 'disrespectful reporting', such as the Observer's apology to the Head of State, Tui Atua Tupua Tamasese Efi, in October over its comments in an editorial about a proposed casino and the Head of State's purported intentions (Apology to his Highness, $S O$, 31 October 2010).

In June 2011, politician Tuala Iosefo Ponifasio' sued Samoan TV3 network manager Atanoa Herbert Crichton and reporter Tutuila Farao for libel (Politician sues network for $\$ 270,000, S O, 15$ June 2011).

\section{Solomon Islands}

Population: 518,321

Form of government: Constitutional monarchy

Languages: English (official), Melanesian dialects

Adult literacy: 76.6 percent

Internet: 3.4 percent 
One daily newspaper in the Solomon Islands, the Solomon Star, has considerable influence and it has a website updated daily. There are also other weekly and monthly newspapers. Radio is critically important with the state-run Solomon Islands Broadcasting Corporation as well as commercial radio. One Television is the only TV channel. The Media Association of the Solomon Islands and RAMSI, which started a Solomon Islands Media Assistance Scheme in 2009 to review the reach and quality of media in the country, are now considering extending the programme into a third phase in conjunction with assistance from the ABC. There is limited access to the internet.

There is free speech and freedom of the press, although there have been harsh penalties through civil actions. In November, the Island Sun was ordered to pay former Prime Minister Dr Derek Sikua and his secretary Jerry Manele a total of $\$ 116,000$ in damages and legal costs when it lost a defamation case.

\section{Tonga}

Population: 101991

Form of government: Constitutional monarchy

Languages: Tongan, English

Adult literacy: 99.2 percent

Internet: 8.4 percent

Tonga has had a history of media abuses. The new government elected in November 2010 has not moved as quickly as some critics expected when former broadcaster and media rights activist 'Akilisi Pohiva, leader of the pro-democracy movement, was elected to government and was widely expected to beccome Prime Minister. Most media were shut out of the swearing in of the new Prime Minister, once again a noble, Lord Tu'ivakano.

There is a well-established government-owned media although private newspapers and broadcasters have been operating in spite of threats of criminal charges and deportation for years. The Tonga Chronicle, a stateowned weekly newspaper, is ironically now managed by the private newspaper Taimi'o 'Tonga, long a critic of the government. Matangi Tonga, an online news service, is also privately owned. As well as other private publications, many of a religious backing, Ko'e Keléa, an independent bimonthly paper, is published in Tongan and English. A new newspaper for women, Faite, was founded in 
October 2010 and in January, Taimi launched its new website Taimi Online www.taimionline.com. The Tonga Broadcasting Commission runs radio and television, while there is also limited private broadcasting.

The Tonga Media Council and the government have been considering introducing freedom of information legislation for years but to date there is no FOI law.

In December 2010, private radio station FM 88.1 was ordered to stop broadcasting as its licence had been repealed. Independent Taimi Media Network publisher Kalafi Moala had decided to start his own radio station and recalled the licence he had 'loaned' to the new station. In February 2011, the government announced it was issuing two new licences (Government grants two new radio licences, TMN, 3 February 2011). The Pacific Freedom Forum criticised the government for planning to introduce a similar licence system for print media (Tonga government and media, PFF, 13 December 2010).

In January 2011, government minister Clive Edwards successfully sued Kele'a newspaper for defamation in the lead-up to the November election. As a result, the IFJ complained and encouraged the Tonga Media Council to work with government and other partners to establish a complaints system, in a bid to keep similar cases out of the courts (IFJ calls for strong independent complaints process in Tonga, IFJ AP Online, 1 February 2011). Edwards' claim was that the 'defamation' (he was alleged with other ministers to have formed a secret party backed by the government) influenced the outcome of the election. The paper was ordered to pay T\$14,275 to Edwards, and was thus made vulnerable to further claims by other members mentioned in the article.

\section{Tuvalu}

Population: 9,561

Form of government: Constitutional monarchy

Languages: Tuvaluan, English

Adult literacy: 93 percent

Internet: 40 percent

Tuvalu has limited media which is wholly owned and operated by the state. The fortnightly Tuvalu Echoes paper is a bilingual publication in English and Tuvaluan. State-owned Radio Tuvalu operates and there is access to cable and satellite television, but no national television. The internet domain .tv is 
popular globally. International media are free to operate in the country. There is no freedom of information legislation or any media council.

No cases of censorship or threats were reported against journalists in the past year. But in January 2011, the government was criticised by the Pacific Freedom Forum for invoking the Public Order Act to ban political meetings for 14 days. The PFF argued the ban would have effects on freedom of the press and expression (More public talking, PFF, 24 January 2011).

\section{Vanuatu}

Population: 224,564

Form of government: Constitutional monarchy

Languages: English

Adult literacy rate: 82 percent

Internet: 7.6 percent

Vanuatu has a developed mediascape, with both state and privately owned outlets. There is the Vanuatu Daily Post and the Vanuatu Times as well as Port Vila Presse and others in English and French. The Vanuatu Broadcasting and Television Corporation runs Television Bilong Vanuatu and Radio Vanuatu and issues radio and television licences. Capital FM is the main private radio station. The Vanuatu Daily Post has an active news website.

Through months of political upheaval in Vanuatu with minority governments and a revolving door leadership with more than five changes of prime minister over the year, there has been heightened sensitivity by the government to media issues. The media was banned from a no-confidence vote in Parliament during December 2010, prompting a protest by the country's media bodies (Vanuatu media disappointed, RNZI, 3 December 2011).

The Media Association of Vanuatu has continued to campaign for freedom of information legislation in Vanuatu, as has the local office of Transparency International. Although there is no media council, Daily Post publisherMarcNeil-Jones made renewed calls for one to beestablished as well as the a complaints procedure after an assault involving a minister in early 2011 (Neil-Jones, 2011). In March, Minister of Public Utilities and Infrastructure Harry Iauko entered the offices of the Vanuatu Daily Post with a group of men and physically and verbally assaulted Marc Neil-Jones. Neil-Jones, who had previously been beaten and deported for his articles and had published 
information from a report that implicated Iauko (Neil-Jones, 2011). The public prosecutor was alleged to have a private interest in the case, being well-known to be a good friend of Iauko. The minister was arrested and charged and in June pleaded guilty. He was fined the equivalent of US\$150.

The sentence was denounced as an outrage by most media groups across the Pacific. Moses Stevens, the ni-Vanuatu president of PINA, condemned the assault but attempted to justify why it might have happened, implying that Neil-Jones had instigated the incident with 'biased reporting', further fuelling the conflict between the media personalities in Vanuatu (PINA condemns attack, PMC, 8 March 2011; Memo to PINA, Café Pacific, 9 March 2011). Neil-Jones reports that threats are common practice in Vanuatu. There is a constant cultural divide between Western attempts to hold the powerful to account and a 'traditional' approach of not taking the government to task. In November, Neil-Jones was opposed by the Media Association Blong Vanuatu when he applied for a radio licence. Reasons given by MAV president Evelyn Toa were that indigenous culture needed to be protected yet Neil-Jones has accused Toa of using her position at MAV to stifle competition for her own media interests.

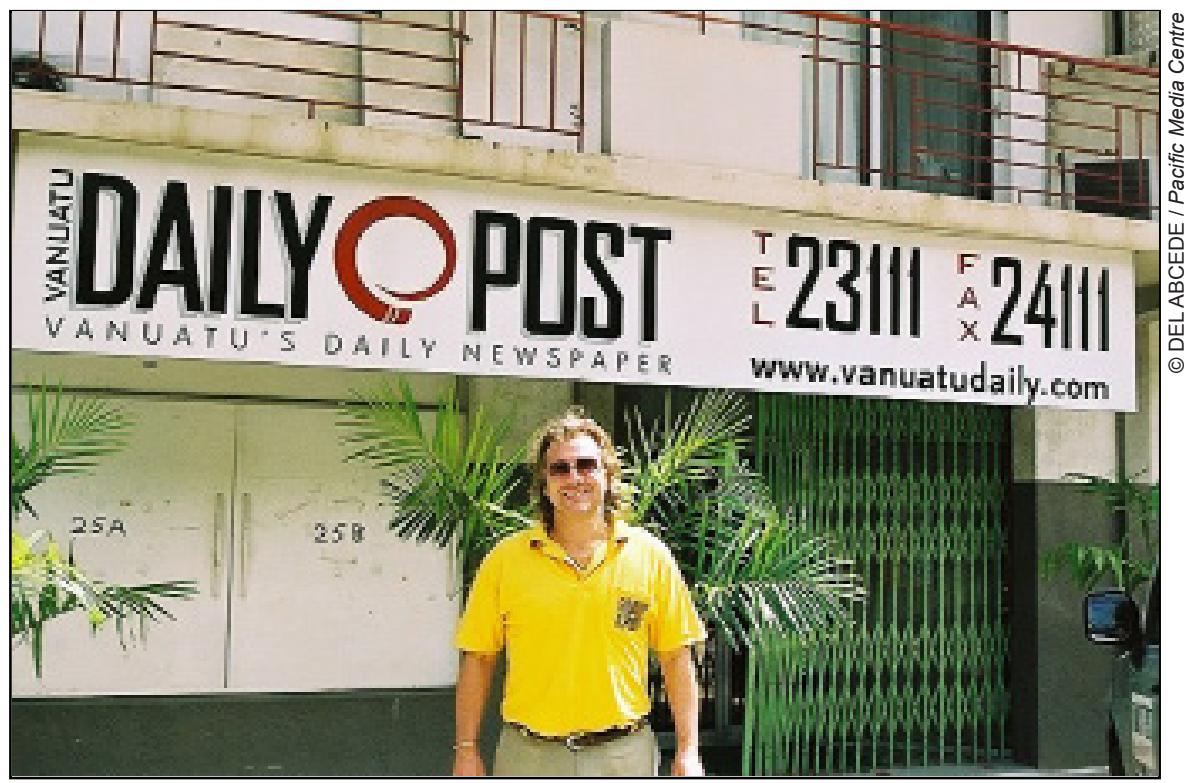

Figure 2: Vanuatu Daily Post publisher Marc Neil-Jones: Target of a political assault.

28 PACIFIC MEDIA FREEDOM 2011: A STATUS REPORT 


\section{Other territories:}

\section{French Polynesia}

Population: 259,596

Form of government: Dependent territory (France)

Languages: Te Reo Māohi and French

Adult literacy: 98 percent

Internet: 40.7 percent

The territory of French Polynesia, or Tahiti, has for the past 12 months felt intense pressure from France to enact reforms of its high-spending public sector. The Bouillet Report has encouraged major cuts to a myriad of 'surplus' public bodies and departments as France puts increased pressure to curb the overspending and reduce its costs in the territory (Call for caution amid French Polynesia's stalled reforms, RNZI, 13 July 2011). The public broadcaster Tahiti Nui TV may well be at risk as the Territorial Assembly is looking to convert it to a web-based service. Some ministers have reacted against the suggestion which would limit access to the television service to less than half the population. The online bilingual (English and French) news service, Tahitipresse, also faces being closed as ministers do not rate the importance of online news in English highly. According to Tahitipresse publisher Thibault Marais: 'At Tahiti Nui TV, you have programmes coming from Pacific countries - some of them are in English and [are being subtitled] in French so that is a good way for people in Tahiti to learn more about the Pacific and to hear it in English as well' (Funding cuts threaten French Polynesian media, RA Pacific Beat, 4 July 2011).

However, the territory enjoys a developed media landscape, with private enterprise as well as state-owned services. There are several private radio stations as well as the RFO Polynesie (French) service. Two daily newspapers, La Dépêche and Les Nouvelles, compete as well as the publication of a monthly paper, Tahiti Pacifique.

In October 2010, $\boldsymbol{U}$-TOPIC, filed a compensation claim against the Tahiti Brewery for alleged vindictive legal action against the small magazine. After being accused of defamation and forging laboratory reports over a 2006 report and since been exonerated, the publication is seeking compensation (Magazine seeks compensation, $P M W, 13$ October 2010). 


\section{New Caledonia}

Population: 245,580

Form of government: Dependent territory (France)

Languages: French (official), Melanesian and Polynesian dialects Adult literacy: 96 percent

Internet: 33.2 percent

There is a range of media outlets in New Caledonia, with a daily newspaper Les Nouvelles Calédoniènnes and the state-owned radio and television service RFO (Maclellan, 2009). Political debate is vibrant on local websites and through locally edited magazines such as Le Pays, the weekly political review Les Infos or the satirical Chien Bleu. There are several private or community run radio stations, including the pro-independence Radio Djiido (www.radiodjiido.nc), Radio Océane FM and Radio RRB, which has an editorial line that usually supports the anti-independence Rassemblement UMP (RUMP) party.

In spite of this diverse media, there are pressures on press freedom, from local political disputes and also changes to media laws that affect France's three Pacific dependencies. Private radio stations in New Caledonia receive grants from the three provincial administrations in New Caledonia, which opens the way for political pressure to be applied. In June and July 2010, Radio Océane FM faced a financial crisis when the Southern Provincial administration refused to pay a scheduled grant to the radio station, at a time when there was political conflict between the three main anti-independence parties. According to the local NGO Ouverture Citoyenne: 'The RUMP majority in the province has blocked the transfer of a grant to Radio Océane, with the reason publicly announced by Mr Lemestre [cabinet director for the province] that the radio station was too critical of his political party. Consequently the radio station may have to end its broadcasts at the end of the month' (Ouverture Citoyenne, 19 June 2010).

For broadcasters in the Noumea offices of the state-run RFO radio and TV stations, operations are affected by a worsening climate for journalists in France. For the first time in 2010, the media watchdog Reporters Sans Frontières added France to its 'Countries under surveillance' list, and the nation dropped to 44th on the annual RSF index.

According to Reporters Without Borders : 'The state of press freedom has been worsening in France for the past several years as a result of tension 
between the press and the authorities, growing pressure on journalists to reveal their sources of information and reform of the public broadcast sector.' Online websites in Noumea are evaluating the implications of changes to domestic security laws over the last year, including the enactment in February 2011 by the French Parliament of the "law on guidelines and programming for the performance of internal security' (Loppsi 2). Provisions of the law institutionalise the administrative filtering of the web without a court order, and while the purported focus is on child pornography, journalists are concerned about the threat it poses to online freedom of expression.

Freedom of the press in France is based on 19th century legislation (Loi sur la liberté de la presse du 29 juillet 1881) which has been regularly amended. In September 2010, the government gazetted a new decree on the media in New Caledonia, French Polynesia and Wallis and Futuna (Décret $n^{\circ}$ 2010-1088 du 15 Septembre 2010 relatif au développement et à la modernisation de la presse en Nouvelle-Calédonie, en Polynésie française et dans les îles Walliset-Futuna). The decree updates a range of laws and regulations governing the media in France's Pacific dependencies.

\section{Timor-Leste (East Timor)}

Population: 1,115,000

Form of government: Republic

Languages: Tetun and Portuguese (English and Indonesian unofficial) Adult literacy: 50.1 percent

Internet: 0.2 percent

Timor-Leste's vibrant media scene continued to grow in 2011 with the launch in early April of the island nation's fourth daily newspaper, The Independente, by a team of young journalists led by former Timor Post editor-inchief Mouzy Lopez.

The country's primary sources of news outside of the capital Dili continued to be a network of 18 regional radio stations plus the state-controlled national radio and TV networks. A second local TV station owned by STL, one of the leading print media houses, launched in 2011 with an eye on a wider audience during the upcoming 2012 elections.

A recent review by major donors of Timor-Leste's media development recommended support for a move by the government and most local journalist associations to unite under an umbrella organisation such as a press council, 
similar to other bodies in the region. It remains unclear how the proposed Press Council would be constituted, how it would operate and how it would be funded. Journalist groups were emphatic it should not be governmentcontrolled.

Ongoing training for Timorese journalists continued to be an issue during 2011 with the impending retreat of the Washington-funded International Centre for Journalists (ICFJ) in Dili. Earlier in 2011, an ICFJ project to launch a community printing centre with donor funding to reduce the high cost of traditional print media was wound up as local stakeholders struggled to take over ownership and meet costs. The National University of East Timor, based in Dili, offers a communications/journalism course in Portuguese and Tetum but was unable to teach updated skills without student internet connections being readily available on campus.

Social media take-up in other Asia-Pacific countries has had little effect on Timor Leste's mediascape due to the high cost to users of a monopoly communications network and limited access outside major centres.

\section{Wallis and Futuna}

Population: 13,445

Form of government: Dependent territory (France)

Languages: Wallisian, French, Futunan

Adult literacy: 50 percent

Internet: 8.4 percent

A limited press exists in Wallis and Futuna after the King of Wallis shut down Te Fenua Fo'ou in 2002. There is 8.4 percent internet penetration but little local news is produced. As well as critical developmental issues and little media in general, there is still an atmosphere of media restriction.

\section{West Papua}

\section{(comprising the provinces of Papua and West Papua)}

Population: 3,612,854

Form of government: Province of Indonesia

Languages: Bahasa Indonesia (official)

Internet: Unlisted

Adult literacy rate: 75 percent, including transmigrants from Indonesia. 
This distorts the overall figure and in some regencies in the Highlands, the literacy rate is as low as 40 percent. Fewer than 56 percent of all people have completed lower primary schooling.

The Indonesian-occupied colony of West Papua is subject to onerous restrictions on press freedom, and repeated cases of direct interference by security forces have been strongly evident in the reportage of the many and complex issues facing the Papuans today. International human rights observers, non-governmental organisations and journalists are severely restricted in their work in Papua amid ongoing reports of serious human rights violations by the police and military.

Jakarta still upholds its prohibition on all foreign journalists and media workers from entering either province in West Papua, unless pre-approved under a slow and bureaucratic process from the Ministry of Information. Even after approval, journalists are always accompanied by a minder from the Badan Intelijen Nasional (National Intelligence Body). Only three foreign journalists have been allowed access to West Papua in 2011. Unsurprisingly, few journalists choose this official route, with many opting to travel into West Papua via unofficial means, a process unavailable to Jakarta-based correspondents under threat of immediate expulsion. Human rights workers regularly report that security forces harass and intimidate those seen talking to foreign journalists, though many still take the risk when a foreign journalist is present.

Until late July 2011, the Indonesian Attorney-General had enforced a ban on all books and publications that discussed Papuan aspirations for independence or advocated peaceful pathways for ending violence in Papua. Under the Sukarno-era 1963 Law on Monitoring Printed Materials with Content that Could Endanger Public Order and the 2004 AGO Law, books by Sofyan Yoman, Benny Giay and others had been denied publication, and their sale or display prohibited. The law was deemed by judicial review as being unconstitutional under the 1945 Indonesian Constitution, which grants freedom for all citizens to 'express their thoughts through verbal and written media'. In practice, even unbanned books have been seized by security forces, but in early August, journalists reported to West Papua Media that thousands of copies of books were replacing betel nut as the main commodity in informal markets. On August 15, the chair of the Dewan Adat Papua, Forkorus Yaboisembut, launched a book challenging the Indonesian government's annexation of Papua, with no seizure of this book evident at time of writing. 
Recent leaked Kopassus (Indonesian Special Forces) documents have demonstrated the pervasiveness of Indonesian security force surveillance into every aspect of Papuan daily life, and media workers are especially under suspicion by Jakarta and the military for supporting separatism simply by reporting on events that concern Papuan people. Both military and 'civilian' intelligence agencies regularly accuse prominent Papuan journalists and media contributors as being both pro-independence and subversive. Several journalists were named in the Anatomy of Papuan Separatists report prepared by Kopassus, and analysed by the West Papua Project at Sydney University (West Papua Project, 2011).

Threats and actual violence against journalists are commonplace in Papua and have been increasing as the civil resistance movement against Indonesian rule has been intensifying. During several mass mobilisations over the past 12 months, security forces have detained journalists from Bintang Papua and other independent media outlets, and reports of militia harassment and threats from the Kopassus backed have also increased. Regular SMS and voicemail harassment messages and death threats have been sent to journalists and human rights workers with a significant escalation in threatening behaviour from military sources since March 2011.

Government or military-controlled media is dominant in Papua, with content being predominantly Java-centric, albeit with some attempts at providing some ethnic Papuan flavour with channels such as Metro Papua TV. However, Papuan and Indonesian journalists alike must contend with the presence of Indonesian intelligence officers sitting in their newsrooms, and regularly either editing their articles, or directly publishing misinformation and propaganda. Several Papuan journalists working for larger outlets have reported to West Papua Media that the behaviour of 'Intel Inside' means they are unable to gain the trust of their sources, which prevents them from doing their job.

Several indigenous independent media organisations have grown throughout 2011, such as Tabloid Jubi and some attempts at beginning indigenous Papuan TV stations, mainly focused on environmental and community issues. However, in Tabloid Jubi's case especially, journalists and editors must regularly contend with the danger of security force intimidation.

The murder of journalist Ardiansyah Matrai'is, who was working with Merauke TV and Jubi, is still unsolved. On 30 July 2010, Matra'is's naked, 
handcuffed body was found in the River Gudang Arand with his arm tied to a tree to prevent his body from floating downstream, and showing signs of torture, according to his autopsy. (Two environmental reporters found dead, IFEX, 11 August 2010; Shanahan, 2010). However, the police concluded he 'committed suicide' (How was investigative reporter pushed to kill himself?, $R S F$, 6 August 2010). Matra' is had been covering plans for the Merauke Integrated Food and Fuel Estate, had received threatening text messages similar to those sent to at least three other local journalists, news reports said. The news website Kompas translated one threat as saying: 'To cowardly journalists, never play with fire if you don't want to be burned. If you still want to make a living on this land, don't do weird things. We have data on all of you and be prepared for death.' Police have still refused to investigate his death any further, and the Alliance of Independent Journalists (AIJ) has taken industrial action on several occasions to advocate for media safety in Papua.

On 24 August 2010, Musa Kondorura, a contributor to Kantor Berita Radio (KBR) $68 \mathrm{H}$ in Wasior Sub-district, Teluk Wondama District, West Papua Province, was attacked by two men, Luki and Hendra, who claimed to be members of the State Intelligence Agency (BIN).

Banjir Ambarita, a journalist with the Jakarta Globe and Bintang Papua, was stabbed in the chest and stomach by two assailants on a motorcycle on March 3 in Jayapura. The attack, widely believed to be by members of the police, happened after Ambarita wrote articles about two alleged rape cases involving the police (Brutal attack, Pacific Scoop, 27 March 2011). Police officers at Jayapura's police detention centre allegedly forced detainees to perform oral sex on police officers from November 2010 to January 2010, and in Biak repeatedly raped and tortured a 15-year-old girl in February 2011. Ambarita's reporting of these cases led to much embarrassment and the resignation of Jayapura Police Chief Adjunct Senior Commissioner Imam Setiawan on 1 March 2011. Unsurprisingly, the police have so far failed to identify the assailants.

In recent and ongoing military operations in Puncak Jaya-where the notorious battalion 753 has been engaged in savage killings of unarmed civilians in reprisal for attacks by the armed resistance of the TPN (Tentara Pembebasan Nasional, or National Liberation Army) - the Indonesian government has closed off access to the Tingginambut district to both Indonesian and foreign human rights and media observers. Local activists have been forced to 
march for days across rugged terrain to deliver verified information. Local human rights observers and Papuan activists from the KNPB have independently reported to West Papua Media that TNI headquarters staff have threatened their safety if they alert journalists to abuses carried out by Indonesian security forces against West Papuan people.

The situation for journalists is not expected to improve in West Papua as long as the international community remains inactive on the issue of media safety and impunity for the security forces in media abuses.

\section{Note}

1. Pacific Islands Forum member countries are Australia, Cook Islands, Federated States of Micronesia, Fiji, Kiribati, Nauru, New Zealand, Niue, Palau, Papua New Guinea, Republic of the Marshall Islands, Samoa, Solomon Islands, Tonga, Tuvalu and Vanuatu. Fiji is currently suspended because the military regime established in December 2006 declined to accelerate plans for a return to democracy with elections scheduled for 2014. French Pacific territories are New Caledonia, French Polynesia and Wallis and Futuna. The Indonesian former and current territories are East Timor (now the independent state of Timor-Leste) and West Papua.

\section{References}

ACT gives govt the necessary numbers to pass surveillance bill (2011, September 21). Radio New Zealand. Retrieved on 21 September, from www.mediawatch. co.nz/news/political/85742/act-gives-govt-the-numbers-to-pass-surveillance-bill

Apology to his highness (2010, October 31). Samoa Observer. Retrieved on 9 August 2011, from www.samoaobserver.ws/index.php?option=com_content\&task=view $\& \mathrm{id}=28930 \&$ Itemid $=62$

Bacon, W., and Price, J. (2011, August 9). The Conversation on Pacific Media Watch. Retrieved on 12 August 2011, from www.pmc.aut.ac.nz/pacific-media-watch/ australia-news-world-scandal-litmus-test-independent-journalism-7570

Brutal attack against journalist Banjir Ambarita (2011, March 27). Pacific Scoop. Retrieved on 19 August 2011, from http://pacific.scoop.co.nz/2011/03/indonesiabrutal-attack-against-journalist-banjir-ambarita/

Call for caution amid French Polynesia's stalled reforms (2011, July 13). Radio NZI. Retrieved on 12 August 2011, from http://www.rnzi.com/pages/news. php?op=read\&id $=61779$

Du Fresne, K. (2011, July 19). How pulling the plug on NZPA will open news cover 'black holes', Pacific Media Centre Online. Retrieved on 8 August 2011, from www.pmc.aut.ac.nz/articles/pulling-plug-nzpa-and-black-holes-news-cover

Field, M. (2010, November 24). Bainimarama: 'I know I am still alive', Stuff website. Retrieved on 22 August 2011, from www.stuff.co.nz/world/south-pacific/4380439/ Bainimarama-I-know-I-am-still-alive 
Fiji Media Watch, (n.d.). The Fiji Media Council code of ethics. Retrieved on 9 August 2011, from www.fijimediawatch.com/index.cfm?go=main. articles\&categoryid=E5483BDC-9AD7-12F0-B9A2CCADCECB4CC9\&subcat egoryid=FE3C5966-B19E-AF5B-20BDE4D67B6F8AC2

Fiji's top businessman jailed (2011, April 14). Stuff Online. Retrieved on 12 August 2011, from www.stuff.co.nz/business/world/4887600/Fijis-top-businessman-jailed Freedom House (2011, August). Freedom of the press 2011: Fiji [Report by David Robie]. Retrieved on 12 August 2011, from www.freedomhouse.org/template. cfm?page $=16$

Funding cuts threaten French Polynesian media and tourism (2011, July 4). RA Pacific Beat. Retrieved on 12 August 2011, from http://www.radioaustralia.net.au/pacbeat/ stories/201107/s3259993.htm

Frank, Uncensored reveals Fiji's coup leader (2010, August 5). ABC Pacific Beat, [Radio interview transcript]. Retrieved on 12 August 2011, from www.radio australia.net.au/pacbeat/stories/201008/s2973996.htm

Government grants two new radio licences (2011, February 3). Taimi Media Network. Retrieved on 8 August 2011, from www.taimionline.com/articles/2006

Grubb, B. (2011, May 17). Security experts go to war: wife targeted, Sydney Morning Herald Online. Retrieved on 19 August 2011, from www.smh.com.au/technology/ security/security-experts-go-to-war-wife-targeted-20110517-1 eqsm.html

Hill, M. (2011, May 15). Campbell Live Samoa complaint rejected, Stuff website. Retrieved on 8 August 2011, from www.stuff.co.nz/entertainment/tv/4905121/ TVNZ-to-fight-BSA-Aramoana-decision

How was investigative journalist pushed to kill himself? (2010, August 6), RSF. Retrieved on 19 August 2011, from http://en.rsf.org/indonesia-how-was-investigative-reporter-06-08-2010,38102.html

IFJ calls for strong independent independent complaints process in Tonga (2011, February 1). IFJ Asia-Pacific Online. Retrieved on 8 August from http://asiapacific. ifj.org/en/articles/ifj-calls-for-strong-independent-complaints-process-in-tonga

Is the government trying to get more control over the media? (2011, September 16). Reporters Without Borders. Retrieved on 20 September 2011, from http://en.rsf. org/australia-is-the-government-trying-to-get-16-09-2011,41007.html

Journalist arrested at IT security conference (2011, May 18). Sydney Morning Herald Online. Retrieved on 8 August 2011, from http://www.smh.com.au/technology/ technology-news/journalist-arrested-at-it-security-conference-20110517-1 erjh. html

Kumar, V. (2010, September 27). Fiji: The best of times, Fiji Media Centre Online. Retrieved on 12 August 2011, from www.pmc.aut.ac.nz/articles/fiji-best-times

McCully complaint against Field story on Fiji upheld (2011. May 11). PMW (Pacific Media Watch) \#7441. Retrieved on 8 August 2011, from www.pmc.aut.ac.nz/pacific-media-watch/2011-05-11/nz-mccullys-complaint-against-field-story-fiji-upheld Maclellan, N. (2009). The changing mediascape in New Caledonia broadens the political spectrum. Pacific Journalism Review, 15(2), pp. 205-209). Retrieved on 
29 August 2011, from http://search.informit.com.au/documentSummary;dn=300 314265572564;res=E-LIBRARY

Magazine seeks compensation from brewery for 'legal abuse' (2010, October 13). PMW (Pacific Media Watch) \#7081. Retrieved on 12 August 2011, from http:// www.pmc.aut.ac.nz/pacific-media-watch/2010-10-13/tahiti-magazine-seekscompensation-brewery-legal-abuse

Media planners, critics tackle shaky future of public television in NZ (2011, June 22). Pacific Scoop. Retrieved on 8 August 2011, from http://pacific.scoop.co.nz/2011/06/ media-planners-critics-tackle-shaky-future-of-public-television-in-nz/

Memo to PINA, get your Vanuatu facts right (2011, March 9). Café Pacific [Blog: David Robie]. Retrieved on 8 August 2011, from http://cafepacific.blogspot. com/2011/03/memo-to-pina-get-your-vanuatu-facts.html

More public talking needed on Tuvalu's public order ban (2011, January 24). PFF (Pacific Freedom Forum). Retrieved on 9 August 2011, from www.pacificfreedomforum.org/2011/01/more-dialogue-discussion-needed-for.html

Motibhai wins race for the Fiji Times, (2010, September 15). Café Pacific [Blog: David Robie]. Retrieved on 12 August 2011, from http://cafepacific.blogspot. com/2010/09/motibhai-wins-race-for-fiji-times.html

Neil-Jones, M. (2011, February 6). World Press Freedom Day in Samoa [Speech]. Retrieved on 8 August 2011, from www.pmc.aut.ac.nz/files/2011-05-06/marc-neiljones-world-press-freedom-day-speech-samoa-2011

New Cook Islands PM sworn in, (2010, November 30). Radio New Zealand International online. Retrieved on 8 August from www.rnzi.com/pages/news. php?op=read\&id $=57367$

New powers mean ASIO could spy on WikiLeaks (2011, May 18). Crikey. Retrieved on 19 August 2011, from www.crikey.com.au/2011/05/18/new-powers-mean-asiocould-spy-on-wikileaks/

New threats to journalists' sources as police secretly access reporter's telephone records, (2010, November 15). IFEX (International Freedom of Expression Exchange). Retrieved on 8 August from www.ifex.org/australia/2010/11/15/ obrien source/

NZPA closing after 132 years (2011, April 6). New Zealand Herald Online. Retrieved on 8 August 2011, from www.nzherald.co.nz/nz/news/article.cfm?c id $=1$ \&objectid $=10717553$

Ouverture Citoyenne (2010, June 19). [Media release].

Palau newspaper closedown highlights media freedom concerns (2011, March 5). PFF (Pacific Media Freedom). Retrieved on 9 August 2011, from www.pacificfreedomforum.org/2011/03/palau-newspaper-closedown-highlights.html

Pasima accuses PINA of being censorship 'lapdog' (2010, December 1). PMC Online (Pacific Media Centre Online). Retrieved on 22 August 2011, from www.pmc.aut.ac.nz/pacific-media-watch/2010-12-01/region-pasima-accuses-pinabeing-censorship-lapdog

Patindol, J. L. C. (2010). Building a peace journalists' network from the ground: 
The Philippine experience. In Keeble, R. L., Tulloch, J., and Zollmann, F. Peace journalism, war and conflict resolution (pp. 193-205). New York: Peter Lang.

Perrottet, A. (2011, May 4). World Press Freedom Day and who's who in Pacific media groups, Pacific Media Watch. Retrieved on 24 August 2011, from www. pmc.aut.ac.nz/pacific-media-watch/2011-05-04/region-world-press-freedom-dayand-whos-who-pacific-media-groups

Perrottet, A. (2010, November 4). Vanuatu media in radio licence row: 'Salesman' $\mathrm{v}$ indigenous newshounds. Pacific Media Centre Online. Retrieved on 22 August 2011, from www.pmc.aut.ac.nz/articles/vanuatu-media-radio-licence-row

PINA condemns attack on newspaper publisher in Vanuatu (2011, March 8). PMC (Pacific Media Centre Online). Retrieved on 8 August 2011, from www.pmc.aut. ac.nz/sites/default/files/file_bin/201103/PINA\%20President $\% 20$ statement $\% 20$ 2011_March8.pdf

Playing the man (2011, May 10). Public Address. Retrieved on 12 August 2011, from http://publicaddress.net/hardnews/playing-the-man/

PNG acting PM accuses Murdoch daily of trying to oust him (2011, July 23). Pacific Scoop. Retrieved on 12 August 2011, from http://pacific.scoop.co.nz/2011/07/ png-acting-pm-accuses-murdoch-daily-of-trying-to-oust-him/

PNG Media Council embroiled in fraud audit (2011, June 3). ABC News Online. Retrieved on 8 August 2011, from www.abc.net.au/news/2011-06-03/png-mediacouncil-embroiled-in-fraud-audit/2744952

Politician sues network for $\$ 270,000$ (2011, June 15). Samoa Observer Online. Retrieved on 8 August 2011, from www.samoaobserver.ws index.php?option=com content\&view=article\&id=33833:-politician-sues\&catid=1:1atestnews\&Itemid $=50$

Progress under liberty: The state of press freedom in Australia 2010 (2010, April 30). MEAA (Media Entertainment and Arts Alliance) [Report]. Retrieved on 8 August 2011, from http://issuu.com/meaa/docs/press freedom 2010

Public Media must be free of government pressure (2010, December 15). RSF (Reporters Without Borders). Retrieved on 8 August 2011, from http://en.rsf.org/ papouasie-nouvelle-guinee-public-media-must-be-free-of-15-12-2010,39041.html

Publisher vows to press assault charges against minister (2011, March 5). PMW (Pacific Media Watch) \#7299. Retrieved on 1 August 2011, from www.pmc.aut. ac.nz/pacific-media-watch/2011-03-05/vanuatu-publisher-vows-press-assaultcharges-against-minister

Rauto, M., and Baselala, E. (2010, September 23). Times change. The Fiji Times. Retrieved on 30 August 2011, from www.fijitimes.com/story.aspx?id=156561

Samoa lacks trained journalists (2011, May 10). Samoa Observer Online. Retrieved on 8 August 2011, from www.samoaobserver.ws/index.php?option=com content $\&$ view $=$ article\&id $=33107$ : samoa-lacks\&catid $=1$ :latest-news \&Itemid $=50$

Shanahan, M. (2010, August 23). They kill environmental journalists, don't they? Under the Banyan [Blog]. Retrieved on 19 August 2011, from http://underthebanyan.wordpress.com/2010/08/23/they-kill-environment-journalists-dont-they/ 
Shanahan, M. W. (2011). A short history of commercial radio in New Zealand. New Zealand Broadcasting School, CPIT, Christchurch New Zealand. Retrieved on 8 August 2011, from www.trb.co.nz/StandardPage.asp?id=180

Simon Overland defends police checks of Herald Sun phone records (2010, September

24) Herald Sun Online. Retrieved on 8 August 2011, from www.heraldsun.com. $\mathrm{au} /$ news/victoria/spy-force-exposed/story-e6frf7kx-1225928598852

Simpson, S. (2011, June 14). Analysis: An overview of the media environment. $P M W$ (Pacific Media Centre Online) \#7499. Retrieved on 9 August 2011, from www. pmc.aut.ac.nz/pacific-media-watch/2011-06-14/fiji-analysis-overview-mediaenvironment

Soerjoatmodjo, G. W. L. (2010). Peace journalism in Indonesia. In Romano, A., International journalism and democracy: Civic engagement models from around the world (pp. 180-193). London: Routledge.

Tan, L. (2010, Dec 9). Defamation kills Korean paper, New Zealand Herald Online. Retrieved on 19 August 2011, from www.nzherald.co.nz/nz/news/article. cfm?c_id=1\&objectid=10693024

Tonga government and media must support complaints process, says PFF (2010, December 13). PFF (Pacific Freedom Forum). Retrieved on 9 August 2011, from www.pacificfreedomforum.org/2010/12/tonga-government-and-media-mustsupport.html

TVNZ to fight Aramoana BSA decision (2011, April 19). Stuff website. Retrieved on 8 August 2011, from www.stuff.co.nz/entertainment/tv/4905121/TVNZ-to-fightBSA-Aramoana-decision

Two environmental journalists found dead; threats to journalists escalate (2010, August 11). IFEX. Retrieved on 19 August 2011, from www.ifex.org/indonesia/2010/08/11/ river dead/

Vanuatu media disappointed over unprecedented ban from Parliament (2011, December 3). Radio New Zealand International. Retrieved on 8 August 2011, from www.rnzi.com/pages/news.php?op=read\&id $=57448$

Vanuatu media in radio licence row (2010, November 4). Pacific Media Centre Online. Retrieved on 1 August 2011, from www.pmc.aut.ac.nz/articles/vanuatumedia-radio-licence-row

Waatea News and Radio New Zealand part company (2011, July 15). Nga Reo Tangata. Retrieved on 8 August 2011, from www.hrc.co.nz/newsletters/diversityaction-programme/nga-reo-tangata/2011/07/waatea-news-and-radio-new-zealandpart-company/

Woods, J. (2010a). Cook Islands: Cook Islands News and the genesis of the FOI. Pacific Journalism Review, 16(2): 15-23.

Woods, J. (2010b, May 3). It's still a fragile freedom [Editorial]. Cook Islands News. Work continues on Fiji Freedom of Information Decree (2011, May 24). Fiji Broadcasting Corporation News. Retrieved on 8 August 2011, from www.radiofiji.com. fj/fullstory.php?id=37038

West Papua Project (2011). Anatomy of an occupation: The Indonesian military in 
West Papua. [Report]. Retrieved on 19 August 2011, from http://sydney.edu.au/ arts/peace_conflict/docs/Anatomy_for_print.pdf

Wilson, S. (2011, September). Muck, brass and circuses. Metro [Editorial], p. 12.

Alex Perrottet is a Masters in Communication Studies postgraduate journalism student at AUT University and has been contributing editor of the Pacific Media Centre's Pacific Media Watch project since mid-2010. Compilation of this research report was assisted by a Faculty of Design and Creative ndustries grant in 2011.

Alex.Perrottet@aut.ac.nz

Dr David Robie is director of the Pacific Media Centre at AUT University, convenor of Pacific Media Watch and he teaches a postgraduate Asia-Pacific Journalism paper. The co-authors thank former PNG Post-Courier publisher and East Timor media consultant Bob Howarth (Papua New Guinea and Timor-Leste), Marshall Islands Journal editor Giff Johnson (Micronesia) freelance journalist and author Nic Maclellan (New Caledonia) and West Papua Media editor Nick Chesterfield (West Papua) for their contributions to this report.

David.Robie@aut.ac.nz 



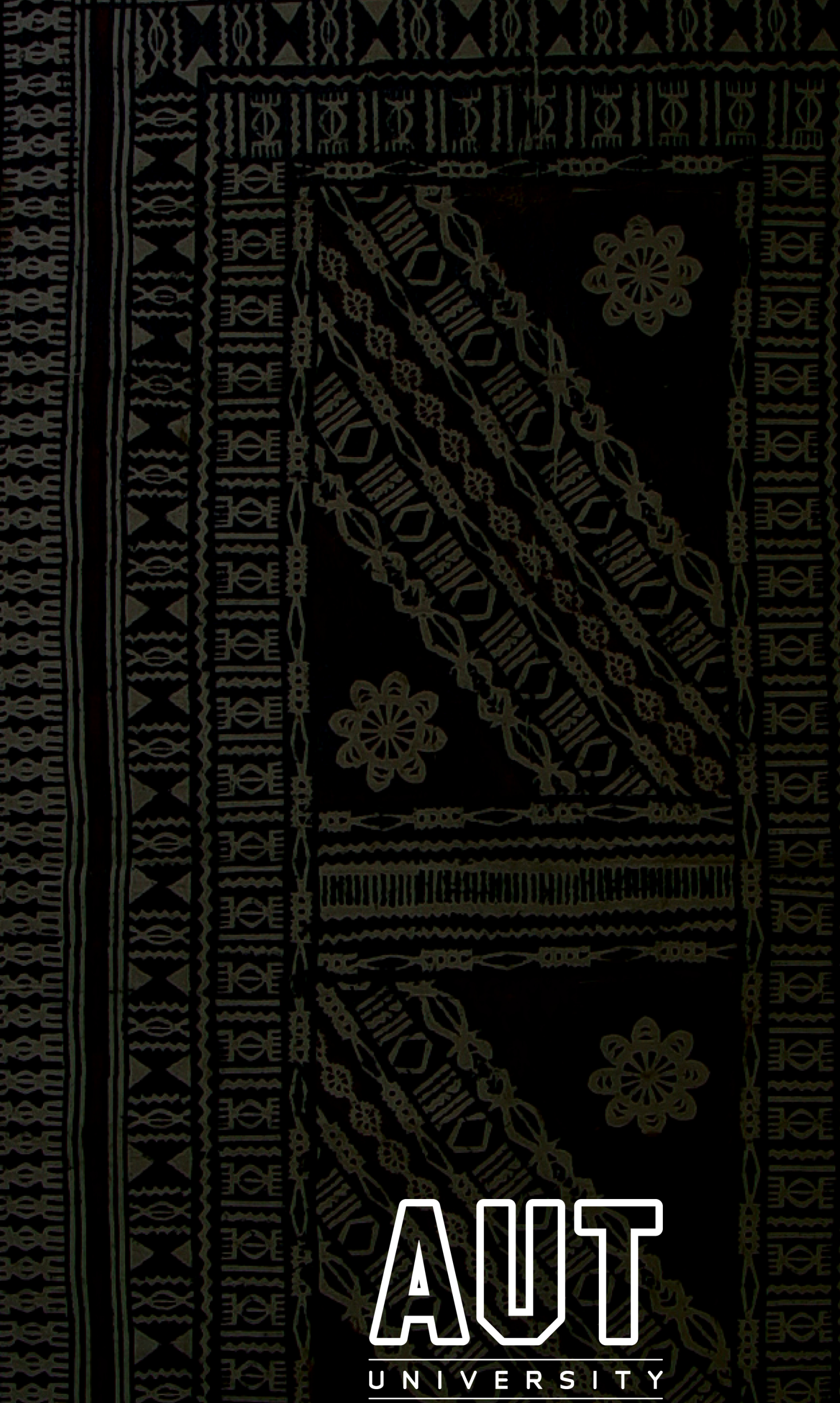

